Boise State University

ScholarWorks

Political Science Faculty Publications and

Presentations

Department of Political Science

6-1-2014

The Conditional Effect of Term Limits on Electoral Activities

Julie VanDusky-Allen

Boise State University 


\title{
The Conditional Effect of Term Limits on Electoral Activities ${ }^{1}$
}

\author{
Julie VanDusky-Allen \\ Department of Public Policy and Administration \\ Boise State University
}

\begin{abstract}
In this paper, I examine how term limits affect the amount of time legislators focus on constituency service and fundraising. I use data from the 2002 US State Legislative Survey conducted by Carey, Niemi, Powell, and Moncrief to provide support for my hypotheses. The results from the data analysis suggest that in the presence of term limits, legislators with longterm career goals in politics spend less time on constituency service activities and more time on fundraising with their caucus. For legislators with short-term career goals in politics, there is very little evidence to suggest that term limits have an effect on how much time they spend on constituency service activities and fundraising activities.
\end{abstract}

\section{Introduction}

Legislative term limits are a rare institutional rule among modern democracies. Countries that have legislative term limits include Costa Rica, Ecuador, Mexico, the Philippines, and the United States (in some US states) (Carey 1996, 3). Several studies have demonstrated that legislators who face term limits behave differently than legislators who do not face term limits (Carey 1996; Carey et al. 2006; Carey, Niemi, and Powell 1998; Drage Bowser and Moncrief 2007; Farmer and Little 2004; Kousser 2005; Meinke and Hasecke 2003; Moncrief, Powell, and Storey 2007; Powell, Niemi, and Smith 2007; Sarbaugh-Thompson et. al. 2006). However, these studies generally do not take into account that term limits do not affect all legislators the same way. In this paper, I argue that term limits affect legislators with long-term political career goals differently than legislators with short-term political career goals. More specifically, I argue that under term limits, legislators with long-term political career goals focus less time catering to their constituents' interests and more time fundraising than they would absent term limits. I argue that we should not see these effects for legislators with short-term political career goals.

In order to demonstrate the varying effects term limits have on legislators' behavior, I analyze how term limits influence the behavior of US state legislators. Legislative term limits were introduced into several US states in the 1990s, and only started to take effect within the last 15 years. I choose to focus on the US because there is a great deal of variation in state legislative institutions within the US. For example, legislative institutions in some US states encourage politicians to pursue long term, state legislative careers (Carey et al. 2006, 122; Wright 2007, 262), while legislative institutions in other states discourage the practice.

A great deal of research has been conducted to assess the effect that term limits have on US state legislators' behavior (Carey et al. 2006; Carey, Niemi, and Powell 1998; Drage Bowser and Moncrief 2007; Farmer and Little 2004; Kousser 2005; Meinke and Hasecke 2003; Moncrief, Powell, and Storey 2007; Powell, Niemi, and Smith 2007; Sarbaugh-Thompson et. al. 2006). In the absence of term limits, career politicians in the US often hold long term, state legislative careers. Since these career legislators need their constituents to get re-elected and maintain a legislative career, this encourages these legislators to focus more on constituency service (Carey, Niemi, and Powell 2000; Berry, Berkman, and Schneirderman 2000; Cox and Morgenstern 1993, 1995; Heitshusen, Young, and Wood 2005; Mayhew 2004; Squire 1988). These legislators also have to spend a great deal of time on catering to local party leaders in order to ensure they win their party’s primary and gain access to the ballot (Breaux and Gierzynski 1991; Gierzynski and Breaux 1991; Grau 1981). In addition, since campaign spending has less of an influence on the vote share of an incumbent legislator than a challenger, this may provide less incentive for legislators to spend a great deal of time on fundraising (Abbe and Herrnson 2003; Breaux and Gierzynski 1991; Gierzynski and Breaux 1991; Giles and Pritchard 1985; Tucker and Weber 1987). In the presence of term limits, however, these same legislators are discouraged from focusing on constituency service. Since these legislators do not need their constituents to continue a career in politics, and since they are forced to find other political positions outside the legislature, they can focus less time on 
constituency service. They can instead focus on activities that will help them get elected to another office, such as fundraising and working with other members of their parties, especially party leaders. These activities make these legislators less responsive to their constituents.

While term limits should influence how much time career politicians spend on constituency service and fundraising, they should not affect how much time legislators with short term political career goals spend on these same activities. Regardless of whether term limits exist, these types of legislators do not plan on maintaining a long term political career. Term limits simply ensure that they leave office as they intend to. Since they do not expect to be in office for the long term regardless of term limits, term limits should not influence how much time they spend on different activities. It is important to note that while these types of legislators should still spend time on constituency service or fundraising, term limits should not influence how much time they spend on these activities.

In order to provide empirical support for my argument, I use constituency service and fundraising questions from the 2002 State Legislative Survey conducted by Carey, Niemi, Powell, and Moncrief. In order to measure the career goals of respondents in the survey, I use two proxy variables: an institutional level variable, (1) state legislative professionalism, and an individual level variable, (2) whether a legislator works for pay outside the legislature. Several studies suggest that more professionalized state legislatures create an environment that fosters the long-term political ambitions of state legislators. Hence, legislators in more professionalized legislatures are more likely to have the resources to maintain long-term political careers than legislators in less professionalized legislatures. In addition, legislators who do not work for pay outside the legislature may be more likely to view politics as a full time job, while those who do work for pay outside the legislature may be more likely to have alternative career goals outside of politics (Carey et al. 2006; Schlesinger 1994; Wright 2007). Hence, identifying whether a legislator works for outside pay is an appropriate way to measure whether a legislator views politics as a career or a short-term career goal.

This paper proceeds as follows: in the next section, I discuss the debate over the effect of term limits on legislators' behavior. In general the debate has focused on the general effect that term limits has had on legislators' behavior. After this discussion, I outline my argument about the conditional effect of term limits on the activities of legislators. Then I discuss the empirical results. The results from the data analysis suggest that in the presence of term limits, legislators with long-term career goals in politics spend less time on constituency service activities and more time on fundraising with their caucus. For legislators with short-term career goals in politics, there is very little evidence to suggest that term limits have had an effect on how much time they spend on constituency service activities and fundraising activities.

\section{US State Legislatures and Term Limits}

In the United States, there are 50 state legislatures, all of which have some kind of plurality rule elections. ${ }^{2}$ Like members of Congress, state legislators tend to serve long legislative careers in part because they have an incumbency advantage when they run for re-election. Data from state legislative election results suggests that more than $90 \%$ of state legislators who run for re-election win (Cox and Morgenstern 1993, 1995; Berry, Berkman, and Schneiderman 2000; Carey, Niemi, and Powell 2000). In the 1980s and 1990s several activists began to regard state legislators' incumbency advantage as a problem. These activists argued that it was too difficult to remove unresponsive legislators from office. Term limits would solve this problem (Carey, Niemi, and Powell 1998; Drage Bowser and Moncrief 2007). As a result of their efforts, several US states introduced term limits for state legislators in the 1990s. By the end of 2002, proponents in 16 states were successful in getting legislative term limits on the books (see Table 1 for a list).

$<$ Table 1 about here $>$

Since term limits have been introduced, there has been a great deal of research on the effect of term limits on legislators' behavior. Some studies suggest that term limits make state legislators less politically ambitious. They suggested that term limits help create citizen legislatures, where civic minded individuals run for office for short periods of time and then return to the private sector (Drage Bowser and Moncrief 2007). In contrast, other research suggests that term limits make legislators even more politically ambitious (Carey et al. 2006). In Ohio, for example, after term limits were introduced, legislators were found to be more concerned about re-election and election to other offices than before term limits. Legislators in Ohio are now much more aggressive at seeking campaign funds than they were before term limits took effect (Farmer and Little 2004). 
Other research has focused on how term limits affect how much time legislators spend on constituency service. For example, evidence from survey research suggests that in term limited states, legislators spend less time on constituency service and securing "pork barrel” projects for their districts than their counterparts in non-term limited states (Carey, Niemi, and Powell 1998; Carey et al. 2006; Powell, Niemi, and Smith 2007). Furthermore, legislators in term limited states are more concerned with following their own conscience and the interests of the state than following the wishes of their constituents. This is especially true for legislators who are closer to their final term (Powell, Niemi, and Smith 2007).

In this paper I contribute to the debate over term limits by demonstrating that term limits do not uniformly affect the amount of time legislators spend on different activities. I argue that the effect that term limits has on these activities of legislators is conditional on a legislator's career goals. More specifically, I only expect term limits to alter the electoral activities of career politicians (Mayhew 2004). I expect that term limits should encourage career politicians to spend less time on constituency service and more time on campaign fundraising activities. In contrast, I do not expect term limits to have an effect on the electoral activities of legislators with short-term career goals in politics.

\section{Constituency Service}

Absent term limits, many American politicians with long-term career goals in politics often serve long state legislative careers. Even if these legislators desire to run for higher office, there may be only a small number of positions outside the state legislature that they could reasonably win (Moncrief et al., 1992; Squire 1988, 2007). This makes a longterm state legislative career more attractive.

In order for career politicians to maintain long legislative careers in a state legislature, they need to focus heavily on constituency service while in office in order to convince their voters to re-elect them. While these legislators do enjoy an incumbency advantage when seeking re-election, they are in large part responsible for building that incumbency advantage. A legislator creates an incumbency advantage by building a relationship with their constituents and focusing heavily on constituency services. These activities help the legislator create a positive reputation with their district, which makes voters more likely to re-elect them (Carey, Niemi, and Powell 2000; Berry, Berkman, and Schneirderman 2000; Cox and Morgenstern 1993, 1995; Heitshusen, Young, and Wood 2005; Mayhew 2004; Squire 1988).

Beyond catering to constituents, a legislator also has to spend a great deal of time building a relationship with his local party leaders and party members, especially if that legislator needs to first win a partisan primary election to re-run for office (Gierzynski and Breaux 1991). This is especially true for legislators in safe districts. In safe districts, primary elections for the dominant party tend to be slightly more competitive than they otherwise would in a non-safe district (Grau 1981). A legislator has to make sure they spend time catering to local party members in order to ensure they gain access to the ballot in future elections.

Term limits present a problem for career politicians who serve as legislators. In the presence of term limits, career politicians cannot be lifetime legislators. They may still desire to hold a legislative seat for a short period of time, but they cannot maintain a long legislative career. If they want to maintain a career in politics, they have to aspire for political positions outside the legislature once they are term limited out. These legislators often run for another office (especially another statewide office) or try to get a non-elective political position in order to maintain a career in politics (Moncrief, Powell, and Storey 2007).

Since career politicians who face term limits aspire for an office outside the districts they represent, they do not rely on their constituents to maintain a long career in politics. Instead, they have to cater to those individuals who determine whether they successfully obtain their next position (i.e. voters in a new constituency or individuals who can appoint them to political positions). Since these legislators do not rely heavily on their constituents to maintain long-term political careers, they have the freedom to spend less time focusing on constituency service. Although these legislators may not completely disregard their constituents, they can spend less time helping their constituents and more time focusing on obtaining their next political position (Maestas 2000; Mayhew 2004; Powell, Niemi, and Smith 2007; Wright 2007). This discussion leads to Hypothesis 1.

Hypothesis 1: Career politicians faced with legislative term limits focus less time on constituency service than career politicians who do not face term limits. 
Unlike career politicians, term limits should not affect how much time legislators with short-term political career goals spend on constituency service. Regardless of term limits, these legislators expect to end their political careers in a short period of time (Meinke and Hasecke 2003). Since these legislators do not expect to have a long-term connection to their constituents with or without term limits, they do not need to focus as much on constituency service in either case. (It is important to note that these legislators may desire to focus on constituency service for reasons other than continuous re-election, but these reasons are should not be associated with term limits). This discussion implies that term limits should have no effect on how much time these types of legislators devote to constituency service.

\section{Campaigning and Fundraising}

Although career politicians who desire to have long-term legislative careers need to focus a great deal on constituency service in order to get re-elected, this is not the only activity they have to focus on. They also have to raise money for their own campaigns. Research has consistently demonstrated that campaign spending has a significant impact in US state legislative elections because campaign spending buys media coverage. Candidates in state legislative elections are generally less visible to the public than candidates in more visible elections (such as gubernatorial elections, congressional elections, and presidential elections). In order for state legislative candidates to increase media coverage, they have to pay for that coverage. And the visibility does have an impact on the candidate's vote share. Candidates who spend more money tend to get more votes (Abbe and Herrnson 2003; Breaux and Gierzynski 1991; Gierzynski and Breaux 1991, 1993; Giles and Pritchard 1985; Tucker and Weber 1987).

Although campaign spending tends to garner votes, incumbent legislators do not have to spend as much on a reelection bid than challengers do. Several studies suggest that incumbent spending in state legislative elections has very little effect on the incumbent's vote share (Abbe and Herrnson 2003; Breaux and Gierzynski 1991; Gierzynski and Breaux 1991; Giles and Pritchard 1985; Tucker and Weber 1987). At least one study even suggests that there is a negative correlation between an incumbent spending in a re-election campaign and the incumbent's vote share (Caldeira and Patterson 1982). These studies do show, however, that a challenger's spending in a campaign against an incumbent does significantly increase the challenger's vote share.

The aforementioned research implies that incumbent legislators do not have to spend as much time focusing on fundraising activities when they seek re-election, since spending money on their campaign will have little effect on their vote share. On the other hand, this research also suggests that term limited legislators who are seeking election to another office do have to spend a great deal of time raising money for their campaigns. This is especially true if the legislator is challenging an incumbent for another statewide office, as it is harder to win an election against an incumbent without spending a great deal of money. Hence, career politicians who face term limits have to a great deal of time on fundraising activities if they want to continue their political careers through another elected office. This discussion leads to Hypothesis 2.

Hypothesis 2: Career politicians faced with legislative term limits focus more time on campaigning and fundraising than their counterparts in non-term limited states.

Unlike career politicians, term limits should have no effect on how much time legislators with short term career goals spend on fundraising activities. Regardless of term limits, these legislators only have short-term political career goals. They care less about re-election, so fundraising and other campaign activities should be a minimum priority regardless of term limits.

In sum, the effect that term limits has on the electoral activities of legislators and political parties is conditional on a legislator's career goals. Term limits alter the amount of time career politicians spend on constituency service. Term limits also alter the amount of time that career politicians spend on campaign and fundraising activities. In contrast, term limits should not alter the amount of time legislators with short term political career goals spend on constituency service. They also should not alter the amount of time that these legislators spend on campaign activities.

\section{Data Analysis}

In order to provide support for Hypotheses 1 and 2, I used data from the 2002 State Legislative Survey conducted by Carey, Niemi, Powell, and Moncrief. I chose this survey because part of its purpose was to assess the impact that term limits had on state legislatures. The authors sent questionnaires to 7,430 state legislators in 50 states in February 2002. 
The questions dealt with topics such as legislative service and legislative parties. The authors received responses from 2,982 legislators. Since members of upper chambers, in short-session states, with small population districts, which were women, and from non-southern states were more likely to respond, the data were weighted for differential response rates. ${ }^{3}$ Below I begin by discussing the research design and results for Hypothesis 1.

\section{Hypothesis 1}

In order to provide empirical support for Hypothesis 1, which dealt with constituency service, I analyzed questions on the survey that dealt specifically with constituency service. The questions read as follows:

(1) “How much time do you spend on each of the following activities?... Keeping in touch with constituents?”

(2) "How much time do you spend on each of the following activities?... Helping constituents with problems with government?"

(3) "How much time do you spend on each of the following activities?... Making sure your district gets a fair share of government money and projects?"

The answers for these three questions ranged from 1 to 5, 1 indicating "Hardly Any” and 5 indicating "A Great Deal.” I used the answers to these questions in six ordinary least squares models.

In each empirical model I included three independent variables of interest: Term Limits, Ambition, and the interaction of Term Limits and Ambition. Term Limits was coded 0 for states without term limits and 1 for states with term limits (see Table 1). Next, I used two proxy variables to capture the political Ambition of each legislator who answered the survey. These variables measured whether legislators were career politicians or short term politicians. The ideal measure for the Ambition variable would have been a question from the survey that asked respondents whether they believed involvement in politics was a long term career goal or just a short term goal. Since this question was not asked, I decided to include two proxy variables instead. I chose one structural level variable, state legislative professionalism (denoted Ambition: Professionalism), and one individual level variable, a question on the survey that asked respondents if they work for pay outside the legislature (denoted Ambition: No Outside Pay).

While all politicians have political ambition, certain characteristics of state legislatures either foster or repress those ambitions (Carey et al. 2006, 122; Schlesinger 1994; Wright 2007, 262). Professionalized legislatures (which have longer session lengths, higher salaries, and a larger staff) tend to attract career politicians because they provide legislators with the resources to foster long term political careers. In contrast, less professionalized legislatures (which have shorter session lengths, lower pay, and a smaller staff) do not provide legislators the resources to foster longterm political careers. Hence, legislators in these states often can only serve short-term political careers (Berry, Berkmand, and Schneiderman 2000; Fiorina 1994; Maddox 2004; Meinke and Hasecke 2003; Moncrief 1988; Moncrief, Powell, and Storey 2007; Mooney 1994; Squire 1988 2007; Wright 2007). In sum, due to structural factors, legislators in more professionalized legislatures are more likely to be career politicians, and legislators in less professionalized legislatures tend to see politics as a short-term goal. Since state legislative professionalism is highly correlated with political ambition (Carey et al. 2006, 122; Wright 2007, 262), I chose state legislative professionalism as one of the proxy variables for political ambition (Ambition: Professionalism). I specifically used Squire's (2007) professionalism of state legislatures index for 2003.

Squire's (2007) professionalism score ranges from 0.027 to 0.626 , with higher numbers indicating that a legislature was more professionalized. The index uses data from the 2003-2004 state legislative sessions. Like other measures of professionalism in the literature, this index includes measures of compensation, session length, and staff for all state legislatures. Squire's measure is unique because it uses the US Congress as a basis of comparison for all state legislatures. Squire used the US Congress because it is the best example of an ideal professionalized legislature in the US. Since the Congress represents an ideal type, it provides an absolute basis for standardization in determining how professionalized each state legislature really is in comparison (Squire 1992, 70-71). For the purposes of these models, I assumed that legislators in more professionalized legislatures were career politicians while legislators in less professionalized legislatures were politicians with short-term career goals. 
Next, I included an individual level proxy variable that captures whether respondents worked for pay outside politics, Ambition: No Outside Pay. The question read as follows: “Do you work for pay outside politics?” I coded the question 0 for Yes and 1 for No. For those individuals who said they did not work for pay outside politics, I assumed that those respondents were career politicians, since their primary source of income was from political activities. I also assumed that individuals who did work for pay outside politics only viewed involvement in politics as a short-term goal. If they were still maintaining an alternative career while serving as a legislator, they were probably less likely to see politics as a permanent career. ${ }^{4}$

Last, I included an interaction term in each model, which was either the product of the Term Limits and Ambition: Professionalism, or Term Limits and Ambition: No Outside Pay. I included these variables because they allowed me to empirically test the effect of Term Limits on legislative behavior based on different levels of Ambition. For each of the two independent variables of interest (Term Limits and Ambition), I did not predict how they would independently affect the amount of time legislators spent on constituency service. Instead I made predictions on their combined effects on the amount of time legislators spend on constituency service. I expected that legislators who were career politicians to spend less time on constituency service when they face term limits. (Or, in other words, I expected that legislators in more professionalized legislators and legislators who did not work for pay outside politics would spend less time on constituency service when they faced with term limits). In addition, I also did not expect term limits to affect the amount of time legislators with short-term political goals would spend on constituency service. (Or, in other words, I did not expect term limits to affect the amount of time legislators in less professionalized legislatures and legislators who did work for pay outside politics spent on constituency service).

Since the hypotheses suggest that the effect of Term Limits on each of the dependent variables varies based on the level of Ambition, including an interaction term in each of the empirical models is the most appropriate way to empirically assess this conditional effect (Brambor, Clark, and Golder 2006; Friedrich 1982). More specifically, with regards to the results of the each model, I do not expect the coefficient for Term Limits to be the same across all observations. I expect it to vary based on the level of Ambition. As I demonstrate below, including an interaction term in each of the models allows me to manipulate the models in such a way that I can determine whether the effect of Term Limts does indeed vary based on the level of Ambition. ${ }^{5}$

In each of the models I also included six control variables that were included in Carey et al.'s (2006) original study: Chamber, Party, Party Controls Chamber, Size of Chamber, South, and Safeness. Chamber is coded 0 for lower chambers and 1 for upper chambers. Party is coded 0 for Republican legislators and 1 for Democratic legislators. Party Controls Chamber is coded 0 if the legislator's party is the minority party in the chamber and 1 if the legislator's party is the majority party in the chamber. Size of Chamber is the number of legislators that serve in the chamber the legislator serves in. South is coded 1 for southern states (as defined by the United States Census Bureau), and 0 for non-southern states. Safeness is a measure that captures how electorally "safe" a legislator feels in their district. It is based on the number of voters from the legislator's party the legislator believes there are in her district versus the number of voters from the opposing party (Carey, Niemi, and Powell 1998, 279). I also included response correction weights in the model (which Carey, Niemi, and Powell (2002) include with their data) and clustered by state. ${ }^{6}$

\section{Results and Discussion}

The results of the first set of empirical models are presented in Table 2 . Since I do not have any theoretical expectations for the independent impact of the three variables of interest (Term Limits, Ambition, and the product of Term Limits and Ambition) on each of the dependent variables, I do not directly interpret the results from Table 2. Instead, I calculated the combined effect of these three variables on each of the dependent variables. Graphs 1 and 2 display the marginal effects of Term Limits on the dependent variables in Models 1 and 3 (Brambor, Clark, and Golder 2006).

$$
<\text { Table } 2 \text { about here }>
$$

Graph 1 displays the marginal effect of Term Limits on Keeping in Touch with Constituents based on different levels of Ambition: Professionalism. The graph demonstrates how the impact of Term Limits changes based on different levels of Ambition. At lower levels of Ambition: Professionalism, the effect of Term Limits is indistinguishable from 0, as the confidence intervals overlap with 0. However, when Ambition: Professionalism reaches about 0.173, it 
becomes clear that the impact of Term Limits becomes negative (as the upper bound of the confidence interval falls below 0). The results suggest that legislators in legislatures with an Ambition: Professionalism index value of 0.173 or higher spend less time on Keeping in Touch with Constituents in the presence of term limits. ${ }^{7}$

The aforementioned results provide support for Hypothesis 1. More politically ambitious legislators (or legislators in more professionalized legislatures) spend less time Keeping In Touch with Constituents when they face term limits. In addition, as expected, Term Limits do not impact the amount of time less politically ambitious legislators (or legislators in less professionalized legislatures) spend on Keeping In Touch with Constituents.

The results from Graph 2 are similar to Graph 1. Graph 2 displays the effect of Term Limits on Helping Constituents with Problems with Government based on different levels of Ambition: Professionalism. At lower levels of Ambition: Professionalism, the marginal effect of Term Limits is indistinguishable from 0. However, when Ambition: Professionalism reaches about 0.20 , slightly higher than average, the impact of Term Limits becomes negative.

These results provide support for Hypothesis 1. More politically ambitious legislators (or legislators in more professionalized legislatures) spend less time Helping Constituents with Problems with Government when they face term limits. In addition, as expected, Term Limits do not impact the amount of time less politically ambitious legislators (or legislators in less professionalized legislatures) spend on Helping Constituents with Problems with Government. Last, the marginal effect of Term Limits was not significant on the Fair Share of Government Money and Projects model for any level of Ambition: Professionalism.

$<$ Graphs 1 and 2 about here $>$

Next, Table 3 displays the results of the effects of Term Limits on each dependent variable based on the Ambition: No Outside Pay models. As expected, more political ambitious legislators (or legislators who do not work for outside pay) spend less time Helping Constituents with Problems with Government and less time making sure their districts gets a Fair Share of Government Money and Projects when they face term limits. In addition, as expected, Term Limits have no effect on the amount of time less politically ambitious legislators spend on

Helping Constituents with Problems with Government and on making sure their district gets a Fair Share of Government Money and Projects.

$<$ Table 3 about here $>$

The results of the control variables in Models 1 to 6 are mixed. The results suggest that Democrats tend to spend more time on constituency service. In addition, legislators whose party controls the legislature spend more time on constituency service. Legislators in larger chambers spend less time on constituency service. Legislators in southern states spend more time on constituency service. And legislators in more safe districts spend more time on constituency service.

In sum, the results from the first six models provide strong support for Hypothesis 1. Career politicians serving as legislators spend less time on constituency service when they face term limits. Absent term limits, career legislators spend a great deal of time catering to constituents in order to get re-elected. In the presence of term limits, however, they spend less time on constituency service. Instead they have to focus on obtaining a future position outside their chamber. As such these legislators are less motivated to cater to their constituents, as their constituents have less control over their ability to obtain their next position. In addition, these legislators have less time to cater to constituents as they have to focus more of their time finding another political position.

\section{Hypothesis 2}

In order to provide empirical support for Hypothesis 2, which dealt campaigning and fundraising, I analyze questions on the survey that dealt specifically with campaigning and fundraising. The questions read as follows:

(1) “How much time do you spend on each of the following activities?... Campaigning and Fundraising?”

(2) "How much time do you spend on each of the following activities?... Fundraising for yourself?"

(3) "How much time do you spend on each of the following activities?... Fundraising for your caucus?" 
The answers for these questions ranged from 1 to 5, 1 indicating "Hardly Any” and 5 indicating "A Great Deal.” I used the answers to these questions as the dependent variable in six ordinary least squares models. I once again included Term Limits, Ambition: Professionalism, and Ambition: No Outside Pay as independent variables of interest in the models. In addition, since I was interested in assessing the combined effects of Term Limits and Ambition on each of the dependent variables, I also included the interaction terms of Term Limits and Ambition in each of the models. I expected term limits to have a positive impact on the amount of time career politicians would spend on campaigning and fundraising. (Or, in other words, I expected that legislators in more professionalized legislators and legislators who did not work for pay outside politics would spend more time on campaigning and fundraising when they faced with term limits). In contrast, I did not expect term limits to affect the amount of time legislators with short term political goals would campaigning and fundraising. (Or, in other words, I did not expect term limits to affect the amount of time legislators in less professionalized legislatures and legislators who did work for pay outside politics spent on campaigning and fundraising).

In the six empirical models I also included six control variables, Chamber, Party, Party Controls Chamber, Size of Chamber, South, and Safeness. I also included response correction weights in the model (which Carey et al. (2002) include with the data) and clustered by state.

$<$ Table 4 about here $>$

\section{Results and Discussion}

The results of the first set of empirical models are presented in Table 4. Since I do not have any theoretical expectations for the independent impact of the three variables of interest (Term Limits, Ambition, and the product of Term Limits and Ambition) on each of the dependent variables, I do not directly interpret the results from Table 4. Instead, I calculated the combined effect of these three variables on each of the dependent variables.

With respect to Models 7 and 9, Term Limits do not have a substantive impact on the amount of time legislators spent on Campaigning and Fundraising, and Fundraising for Yourself. However, Term Limits do have an effect on Fundraising for Your Caucus. As Graph 3 demonstrates, at lower levels of Ambition: Professionalism, the marginal effect of Term Limits is indistinguishable from 0. However, when Ambition: Professionalism reaches about 0.20, slightly higher than average, the impact of Term Limits becomes positive, as the lower bound of the confidence interval rises above 0 . These results suggest that legislators who are career politicians (or legislators in more professionalized legislatures) who face term limits spend more time on fundraising for their caucus than their counterparts in non-term limited states. In addition, as expected, the results suggest that Term Limits do not have an impact on the amount of time legislators who are not career politicians (or politicians in less professionalized legislators) spend on fundraising for their caucus.

$<$ Graph 3 about here $>$

Table 5 displays the impact of Term Limits in the Ambition: No Outside Pay models. The results are similar to the results from the previous models. They suggest that legislators who are career politicians (or legislators who do not work for outside pay) spend more time on fundraising for their caucus when they face term limits. In addition, as expected, Term Limits do not have an impact on the amount of time legislators who are not career politicians (or politicians who do work for outside pay) spend on fundraising for their caucus.

$<$ Table 5 about here $>$

The results from Models 7 through 12 imply that the impact that Term Limits have on how career politicians campaign and fundraise is more nuanced that originally expected. The results suggest that when career politicians face term limits, they spend more time working with members of their political parties on campaigning and fundraising activities. Although this topic is beyond the scope of this paper, it is important to note, given these results, that some studies suggest that political parties in term limited states play a more active role in helping legislators maintain long term political careers. For example, experts have observed that after term limits came into effect in California, Michigan, and Ohio, legislators placed more emphasis on fundraising ability when selecting their legislative party leaders. In addition, party leaders in Ohio have taken advantage of Ohio's vacancy appointment law to help term 
limited legislators find new positions and help new legislators run as incumbents. Party leaders reward term-limited legislators who resign midterm with appointments to vacant seats in other offices, and then replace the legislator with another loyal party member, who can run as an incumbent in the subsequent election (Farmer and Little 2004, 6). ${ }^{8}$

Last, the results of the control variables in Models 7 to 12 are mixed. The results suggest that Democrats tend to spend more time campaigning and fundraising. Legislators whose party controls the legislature spend less time campaigning and fundraising. Legislators in larger chambers spend less time campaigning and fundraising. Legislators in southern states spend more time campaigning and fundraising. And legislators who are in more safe districts spend more time campaigning and fundraising.

\section{Conclusion}

It appears that, based on the results of this paper, term limits have led to unintended consequences for some US state legislatures. Instead of producing more civic minded legislators in these states, term limits have instead produced legislators that are less responsive to their constituents. When faced with term limits, full time legislators and legislators in more professionalized legislatures spend less time keeping in touch with constituents, less time helping their constituents with problems with government, and less time making sure their districts get a fair share of government money and projects. Instead of focusing more on constituency service, these legislators are likely spending more time focusing on obtaining their next political positions. These legislators are spending more time fundraising with their co-partisans and, based on anecdotal evidence from states like Ohio, are working more closely with their party leaders to obtain positions outside their current chamber.

Lawmakers and citizens in democracies throughout the world can use the US experience with legislative term limits as a guide when deciding whether to introduce term limits. It is important to take into account that term limits should have varying effects on legislative and political behavior in difference institutional environments. For example, Mexico had term limits throughout most of the $20^{\text {th }}$ century, but term limits could not prevent a single party, the PRI, from controlling Mexican elections until the end of the century. Costa Rica, on the other hand, has had a difference experience with term limits. It enjoys being one of the oldest institutionalized democracies in Latin America. Based on the results of this paper, we also see variations in the effects of term limits with the US states, suggesting once again that the broader institutional environment influences how term limits affect legislative and political behavior. Absent term limits, certain state legislatures foster a professional environment where legislators are encouraged to treat serving as a full time, career position. Introducing term limits in these legislatures alters these norms, and may encourage legislators to focus less time on their legislative duties.

The results of this paper also speak to a large body of literature that focuses on the campaigning and fundraising activities of political parties. The amount of time and resources political parties spend on running elections is in part determined by the electoral goals of its members (Aldrich 1995; Cox 2006; Cox and McCubbins 1993; Gunther and Diamond 2003; Janda et al. 1995; King 1969; Müller 1997; Müller and Strøm 1999; Schlesinger 1994). Since the nature of a party is determined by the demands of its members, if we want to understand, explain, and predict what a political party does, then we need to identify the goals of its members. We also need to understand the broader institutional environment in which politicians exist as this influences how political parties help their members achieve their goals (Amorim Neto and Cox 1997; Cox, Rosenbluth, and Thies 1999, 2000; Fillipov, Ordeshook, and Shvetsova 2004; Ordeshook and Shvetsova 1994). Since term limits alter the specific long term career goals of career politicians, they should affect what those politicians need to do to re-elected, and this may potentially alter what parties have to do to help their members maintain long term political careers. The results of this paper suggest just this, that parties in term limited states take a more active role helping their members achieve their long term political goals. Parties can help provide the resources for their term limited members to win elections in other offices. In addition, a party can help a term limited legislator get appointed to another elected office midterm. Hence, it is possible that term limits have produced another unintended consequence in several US states- making legislators rely more heavily on their parties to maintain a career in politics. 


\section{Bibliography}

Abbe, Owen G. and Paul S. Herrnson. 2003. “Campaign Professionalism in State Legislative Elections.” State Politics and Policy Quarterly 3(3): 223-245. Accessed on March 10, 2014. Available online at http://spa.sagepub.com/content/3/3/223.abstract

Aldrich, John .H. 1995. Why Parties? The Origin and Transformation of Political Parties in America. Chicago: The University of Chicago Press.

Amorim Neto, Octavio . and Gary W. Cox. 1997. "Electoral Institutions, Cleavage Structures, and the Number of Parties.” American Journal of Political Science 41(1): 149-174. Accessed on March 10, 2014. Available online at http://www.jstor.org/discover/10.2307/2111712?uid=3739696\&uid=2134\&uid=2\&uid=70\&uid=4\&uid= $\underline{3739256 \& \text { sid }=21103710660153}$

Berry, William D., Michael B. Berkman, and Stuart Schneiderman. 2000. "Legislative Professionalism and Incumbent Reelection: The Development of Institutional Boundaries.” The American Political Science Review 94(4): 859-874. Accessed on March 10, 2014. Available online at http://www.jstor.org/discover/10.2307/2586212?uid=3739696\&uid=2134\&uid=2\&uid=70\&uid=4\&uid= 3739256\&sid $=21103710660153$

Brambor, Thomas, William Roberts Clark, and Matt Golder. 2006. "Understanding Interaction Models: Improving Empirical Analyses.” Political Analysis 14(1): 63-82. Accessed on March 10, 2014. Available online at http://pan.oxfordjournals.org/content/14/1/63.abstract

Breaux, David A. and Gierzynski, Anthony. 1991. "It’s Money that Matters: Campaign Expenditures and State Legislative Primaries.” Legislative Studies Quarterly 16(3): 429-443. Accessed on March 10, 2014. Available online at http://www.jstor.org/discover/10.2307/440106?uid=3739696\&uid=2134\&uid=2\&uid=70\&uid=4\&uid=3 $\underline{739256 \& \text { sid }=21103710660153}$

Caldeira, Gregory A. and Samuel C. Patterson. 1982. "Bringing Home the Votes: Electoral Outcomes in State Legislative Races.” Political Behavior 4(1): 33-67. Accessed on March 10, 2014. Available online at http://link.springer.com/article/10.1007/BF00987118

Carey, John M. 1996. Term Limits and Legislative Representation. Cambridge: Cambridge University Press.

Carey, John M., Richard G. Niemi, and Lynda W. Powell. 1998. "The Effects of Term Limits on State Legislatures." Legislative Studies Quarterly 23(2): 271-300. Accessed on March 10, 2014. Available online at http://www.jstor.org/discover/10.2307/440283?uid=3739696\&uid=2134\&uid=2\&uid=70\&uid=4\&uid=3 $739256 \&$ sid $=21103710660153$

Carey, John M., Richard G. Niemi, and Lynda W. Powell. 2000. Term Limits in the State Legislatures. Ann Harbor: The University of Michigan Press.

Carey, John M., Richard G. Niemi, Lynda W. Powell, and Gary Moncrief. 2006. "The Effects of Term Limits on State Legislatures: A New Survey of the 50 States.” Legislative Studies Quarterly 31 (1): 105-134. Accessed on March 10, 2014. Available online at http://onlinelibrary.wiley.com/doi/10.3162/036298006X201742/abstract

Carey, John M., Richard G. Niemi, Lynda W. Powell, and Gary Moncrief. 2002 STATE LEGISLATIVE SURVEY [Computer file]. ICPSR20960-v1. Rochester, NY: University of Rochester [producer], 2002. Ann Arbor, MI: Inter-university Consortium for Political and Social Research [distributor], 2008-03-25. doi:10.3886/ICPSR20960

Cox, Gary W. 2006. “The Organization of Democratic Legislatures”. In Weingast, Barry R. and Donald A. Wittman, eds., Oxford Handbook of Political Economy. Oxford: Oxford University Press. 141-161.

Cox, Gary W. and Mathew D. McCubbins. 1993. Legislative Leviathan: Party Government in the House. Berkeley: University of California Press.

Cox, Gary W. and Scott Morgenstern. 1993. "The Increasing Advantage of Incumbency in the U.S. States.” Legislative Studies Quarterly 18(4): 495-514. Accessed on March 10, 2014. Available online at http://www.jstor.org/discover/10.2307/439852?uid=3739696\&uid=2134\&uid=2\&uid=70\&uid=4\&uid=3 739256\&sid=21103710660153

Cox, Gary W. and Scott Morgenstern. 1995. "The Incumbency Advantage in the Multimember Districts: Evidence from the U.S. States.” Legislative Studies Quarterly 20(3): 329-349. Accessed on March 10, 2014. Available online at http://www.jstor.org/discover/10.2307/440224?uid=3739696\&uid=2134\&uid=2\&uid=70\&uid=4\&uid=3 $\underline{739256 \& \text { sid }=21103710660153}$ 
Cox, Gary W., Frances M. Rosenbluth, and Michael F. Thies. 1999. "Electoral Reform and the Fate of Factions: The Case of Japan's Liberal Democratic Party." British Journal of Political Science 29(1): 33-56. Accessed on March 10, 2014. Available online at http://journals.cambridge.org/action/displayAbstract?fromPage=online\&aid=1371\&fulltextType=RA\&fi leId=S0007123499000022

- 2000. "Electoral Rules, Career Ambitions, and Party Structure: Comparing Factions in Japan's Upper and Lower House." American Journal of Political Science 44(1):115-22. Accessed on March 10, 2014.

Available online

at http://www.jstor.org/discover/10.2307/2669297?uid=3739696\&uid=2134\&uid=2\&uid=70\&uid=4\&uid= $\underline{3739256 \& \text { sid }=21103710660153}$

Drage Bowser, Jennie and Gary Moncrief. 2007. “Term Limits in State Legislatures.” In Kurtz, Karl T., Bruce Cain, and Richard Niemi, eds., Institutional Change in American Politics, The Case of Term Limits. Ann Harbor: University of Michigan Press. 10-21.

Farmer, Rick and Thomas H. Little. 2004. "Legislative Power in the Buckeye State: The Revenge of Term Limits: Final Report for the Joint Project on Term Limits.” Joint Project on Term Limits, National Conference of State Legislatures. Denver. Accessed on March 10, 2014. Available online at http://www.ncsl.org/Portals/1/documents/jptl/casestudies/OHFamer_Littlev2.pdf

Fillipov, Mikhail, Peter Ordeshook, and Olga Shvetsova. 2004. Designing Federalism, A Theory of Self-Sustainable Federal Institutions. Cambridge: Cambridge University Press.

Fiorina, Morris. 1994. "Divided Government in the American States: A Byproduct of Legislative Professionalism?” American Political Science Review 88(2): 304-316. Accessed on March 10, 2014. Available online at http://www.jstor.org/discover/10.2307/2944705?uid=3739696\&uid=2134\&uid=2\&uid=70\&uid=4\&uid= $\underline{3739256 \& \text { sid }=21103710660153}$

Friedrich, Robert J. 1982. "In Defense of Multiplicative Terms in Multiple Regression Equations.” American Journal of Political Science 26(4): 797-833. Accessed on March 10, 2014. Available online at http://www.jstor.org/discover/10.2307/2110973?uid=3739696\&uid=2134\&uid=2\&uid=70\&uid=4\&uid= $\underline{3739256 \& \text { sid }=21103710660153}$

Gierzynski, Anthony and David Breaux. 1991. "Money and Votes in State Legislative Elections.” Legislative Studies Quarterly 16(2): 203-217. Accessed on March 10, 2014. Available online at http://www.jstor.org/discover/10.2307/439978?uid=3739696\&uid=2134\&uid=2\&uid=70\&uid=4\&uid=3 $\underline{739256 \& \text { sid }=21103710660153}$

Gierzynski, Anthony and David Breaux. 1993. "Money and the Party Vote in State House Elections.” Legislative Studies Quarterly 18(4): 515-533. Accessed on March 10, 2014. Available online at http://www.jstor.org/discover/10.2307/439853?uid=3739696\&uid=2134\&uid=2\&uid=70\&uid=4\&uid=3 739256\&sid $=21103710660153$

Giles, Michael W. and Anita Pritchard, A. 1985. "Campaign Expenditures and Legislative Elections in Florida.” Legislative Studies Quarterly 10(1): 71-88. Accessed on March 10, 2014. Available online at http://www.jstor.org/discover/10.2307/440116?uid=3739696\&uid=2134\&uid=2\&uid=70\&uid=4\&uid=3 $\underline{739256 \& \text { sid }=21103710660153}$

Grau, Craig H. 1981. “Competition in State Legislative Primaries.” Legislative Studies Quarterly 6(1): 35-54. Accessed on March 10, 2014. Available online at http://www.jstor.org/discover/10.2307/439712?uid=3739696\&uid=2134\&uid=2\&uid=70\&uid=4\&uid=3 $\underline{739256 \& \text { sid }=21103710660153}$

Gunther, Richard and Larry Diamond. 2003. "Species of Political Parties: A New Typology.” Party Politics 9(2): 167-199. Accessed on March 10, 2014. Available online at http://ppq.sagepub.com/content/9/2/167.abstract

Heitshusen, Valerie, Garry Young, and David M. Wood. 2005. "Electoral Context and MP Constituency Focus in Australia, Canada, Ireland, New Zealand, and the United Kingdom.” American Journal of Political Science 49(1): 32-45. Accessed on March 10, 2014. Available online at http://onlinelibrary.wiley.com/doi/10.1111/j.0092-5853.2005.00108.x/abstract

Janda, Kenneth, Robert Harmel, Christine Edens, and Patricia Goff. 1995. "Changes in Party Identity: Evidence from Party Manifestos.” Party Politics 1(2): 171-196. Accessed on March 10, 2014. Available online at http://ppq.sagepub.com/content/1/2/171.abstract

King, Anthony. 1969. "Political Parties in Western Democracies: Some Skeptical Reflections." Polity 2(2): 111-141. Accessed on March 10, 2014. Available online at http://www.jstor.org/discover/10.2307/3234095?uid=3739696\&uid=2134\&uid=2\&uid=70\&uid=4\&uid= $\underline{3739256 \& \operatorname{sid}=21103710660153}$ 
This is an author-produced, peer-reviewed version of this article. The final, definitive version of this document can be found online at Politics \& Policy, published by Wiley-Blackwell. Copyright restrictions may apply. doi: 10.1111/polp.12072

Kousser, Thad. 2005. Term Limits and the Dismantling of State Legislative Professionalism. New York: Cambridge University Press.

Maddox, H.W. Jerome. 2004. “Opportunity Costs and Outside Careers in US State Legislatures.” Legislative Studies Quarterly 29(4): 517-544. Accessed on March 10, 2014. Available online at http://onlinelibrary.wiley.com/doi/10.3162/036298004X201285/abstract

Maestas, Cheire. 2000. "Professional Legislatures and Ambitious Politicians: Policy Responsiveness of State Institutions.” Legislative Studies Quarterly 25(4): 663-690. Accessed on March 10, 2014. Available online at http://www.jstor.org/discover/10.2307/440439?uid=3739696\&uid=2134\&uid=2\&uid=70\&uid=4\&uid=3 $739256 \&$ sid $=21103710660153$

Mayhew, David R. 2004. Congress, The Electoral Connection. New Haven: Yale University Press.

Meinke, Scott R. and Edward B. Hasecke. 2003. "Term Limits, Professionalization, and Partisan Control in U.S. State Legislatures.” The Journal of Politics 65(3): 898-908. Accessed on March 10, 2014. Available online at http://onlinelibrary.wiley.com/doi/10.1111/1468-2508.00218/abstract

Moncrief, Gary F. 1988. "Dimensions of the Concept of Professionalism in State Legislatures: A Research Note.” State and Local Government Review 20(3): 128-132. Accessed on March 10, 2014. Available online at http://www.jstor.org/discover/10.2307/4354942?uid=3739696\&uid=2134\&uid=2\&uid=70\&uid=4\&uid= 3739256\&sid $=21103710660153$

Moncrief, Gary F., Joel A. Thompson, Michael Haddon, and Robert Hoyer. 1992. "For Whom the Bell Tolls: Term Limits and State Legislatures.” Legislative Studies Quarterly 17(1): 37-47. Accessed on March 10, 2014. Available online at http://link.springer.com/chapter/10.1007\%2F978-94-009-1812-2_8

Moncrief, Gary F., Lynda W. Powell, and Tim Storey. 2007. “Composition of Legislatures.” In Kurtz, Karl T., Bruce Cain, and Richard Niemi, eds., Institutional Change in American Politics, The Case of Term Limits. Ann Harbor: University of Michigan Press. 22-37.

Mooney, Christopher Z. 1994. "Measuring U.S. State Professionalism: An Evaluation of Five Indices.” State and Local Government Review 26(2): 70-78. Accessed on March 10, 2014. Available online at http://www.jstor.org/discover/10.2307/4355086?uid=3739696\&uid=2134\&uid=2\&uid=70\&uid=4\&uid= 3739256\&sid $=21103710660153$

Müller, Wolfgang C. 1997. "Inside the Black Box: A Confrontation of Party Executive Behaviour and Theories of Party Organizational Change.” Party Politics 3(3): 293-313. Accessed on March 10, 2014. Available online at http://ppq.sagepub.com/content/3/3/293.abstract

Müller, Wolfgang C. and Kaare Strøm, eds. 1999. Policy, Office, or Votes: How Political Parties in Western Europe Make Hard Decisions. Cambridge: Cambridge University Press.

National Council of State Legislatures (NCSL). 2002. "Idaho Makes Term Limits History.” Accessed on March 10, 2014. Available online at http://archive.is/c9L6

National Council of State Legislatures (NCSL). 2010. “The Term Limited States.” Accessed on $\quad$ March 10, 2014. Available online at http://www.ncsl.org/research/about-state-legislatures/chart-of-term-limits-states.aspx

National Council of State Legislatures (NCSL). 2011a. "Elections and Campaigns.” Accessed on March 20, 2014. Available online at http://www.ncsl.org/research/elections-and-campaigns.aspx\#1116

National Council of State Legislatures (NCSL). 2011b. "Legislative Term Limits: An Overview.” Accessed on March 10, 2014. Available online at http://www.ncsl.org/research/about-state-legislatures/legislative-termlimits-overview.aspx

Ordeshook, Peter C. and Olga Shvetsova. 1994. "Ethnic Heterogeneity, District Magnitude, and the Number of Parties.” American Journal of Political Science 38(1): 100-123. Accessed on March 10, 2014. Available online at http://www.jstor.org/discover/10.2307/2111337?uid=3739696\&uid=2134\&uid=2\&uid=70\&uid=4\&uid= 3739256\&sid $=21103710660153$

Powell, Lynda W., Richard G. Niemi, and Michael Smith. 2007. "Constituent Attention and Interest Representation.” In Kurtz, Karl T., Bruce Cain, and Richard Niemi, eds., Institutional Change in American Politics, The Case of Term Limits. Ann Harbor: University of Michigan Press. 38-54.

Sarbaugh-Thompson, Marjorie, Lyke Thompson, Charles D. Elder, John Strate, and Richard C. Elling. 2006. The Political and Institutional Effects of Term Limits. New York: Palgrave Macmillan Press.

Schlesinger, Joseph A. 1994. Political Parties and the Winning of Office. Ann Harbor: The University of Michigan Press. 
Squire, Pervill. 1988. “Career Opportunities and Membership Stability in State Legislatures.” Legislative Studies Quarterly 13(1): 65-82. Accessed on March 10, 2014. Available online at http://www.jstor.org/discover/10.2307/439945?uid=3739696\&uid=2134\&uid=2\&uid=70\&uid=4\&uid=3 739256\&sid=21103710660153

_ 1992. "Legislative Professionalism and Membership Diversity in State Legislatures.” Legislative Studies Quarterly 17(1): 69-79.

— 2007. "Measuring State Legislative Professionalism: The Squire Index Revisited." State Politics and Policy Quarterly 7(2): 211-227. Accessed on March 10, 2014. Available online at http://spa.sagepub.com/content/7/2/211.abstract

Tucker, Harvey J. and Ronald E. Weber. 1987. "State Legislative Election Outcomes: Contextual Effects and Legislative Performance Effects.” Legislative Studies Quarterly 12(4): 537-553. Accessed on March 10, 2014. Available online at http://www.jstor.org/discover/10.2307/439747?uid=3739696\&uid=2134\&uid=2\&uid=70\&uid=4\&uid=3 739256\&sid=21103710660153

Wright, Gerald C. 2007. "Do Term Limits Affect Legislative Roll Call Voting? Representation, Polarization, and Participation.” State Politics and Policy Quarterly 7(3): 256-280. Accessed on March 10, 2014. Available online at http://spa.sagepub.com/content/7/3/256.abstract 


\section{Appendix: Tables and Figures}

\begin{tabular}{|c|c|}
\hline \multicolumn{2}{|c|}{ Table 1: Term Limits in State Legislatures } \\
\hline State & Year Adopted \\
\hline Arizona & 1992 \\
\hline Arkansas & 1992 \\
\hline California & 1990 \\
\hline Colorado & 1990 \\
\hline Florida & 1992 \\
\hline Louisiana & 1995 \\
\hline Maine & 1993 \\
\hline Michigan & 1992 \\
\hline Missouri & 1992 \\
\hline Montana & 1992 \\
\hline Nebraska & 2000 \\
\hline Ohio & 1992 \\
\hline Oklahoma & 1990 \\
\hline South Dakota & 1992 \\
\hline Utah & 1994 \\
\hline Wyoming & 1992 \\
\hline Source: National Council of State Legislatures (2011b) \\
\hline \multicolumn{2}{|l}{} \\
\hline
\end{tabular}


This is an author-produced, peer-reviewed version of this article. The final, definitive version of this document can be found online at Politics \& Policy, published by Wiley-Blackwell. Copyright restrictions may apply. doi: 10.1111/polp.12072

Table 2: Constituency Service Models

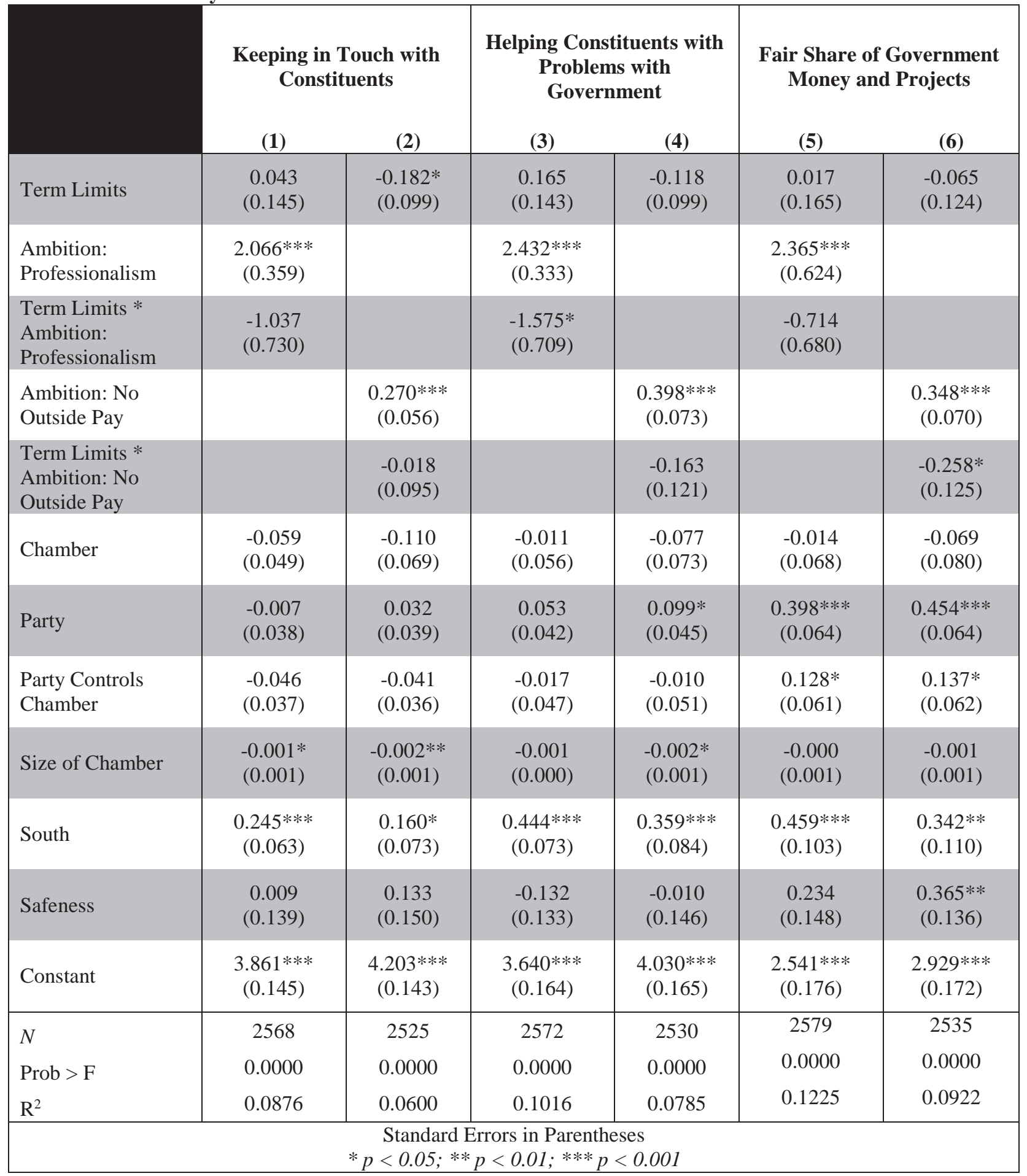


Graph 1: The Marginal Effect of Term Limits on Keeping in Touch with Constituents

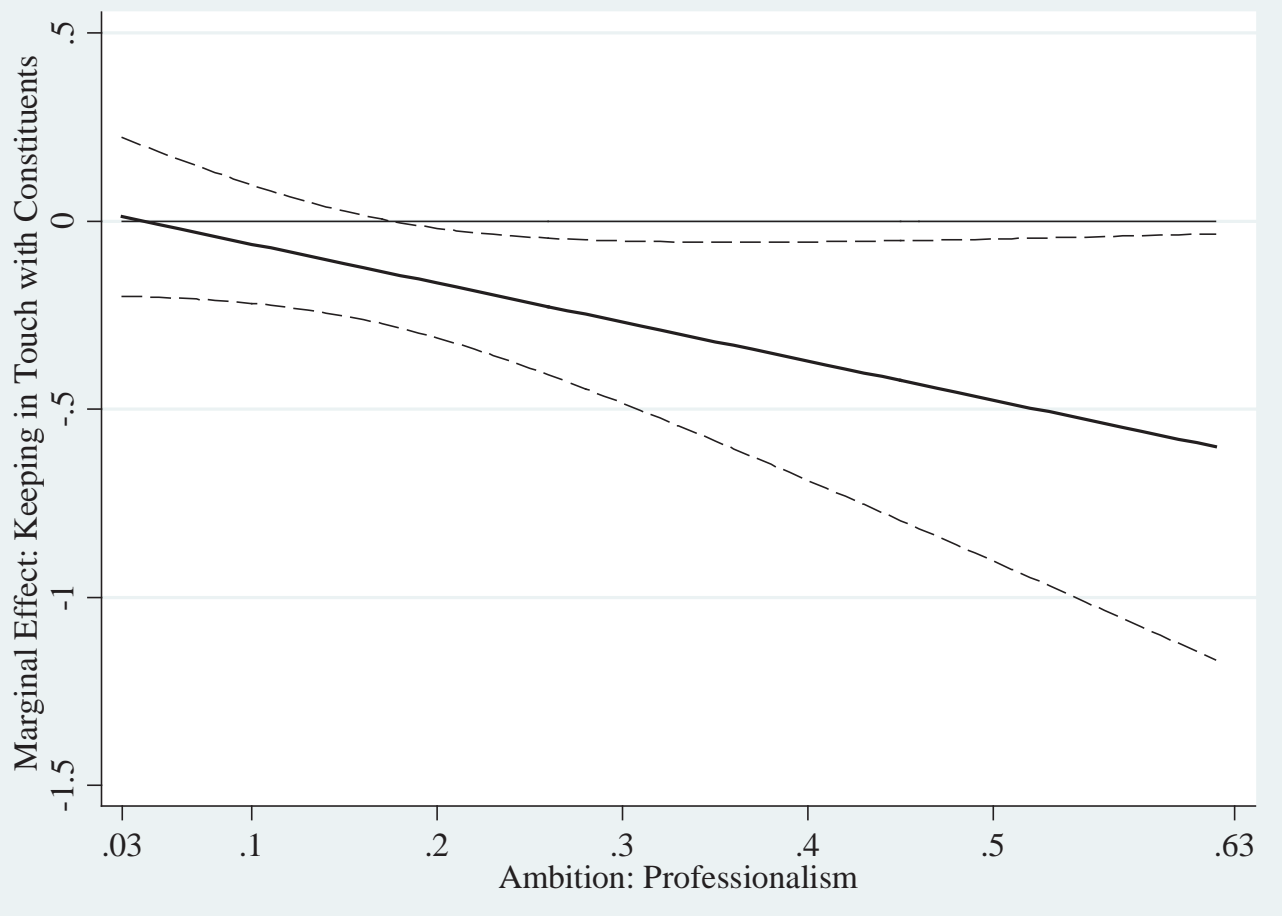

Graph 2: The Marginal Effect of Term Limits on Helping Constituents with Problems with Government

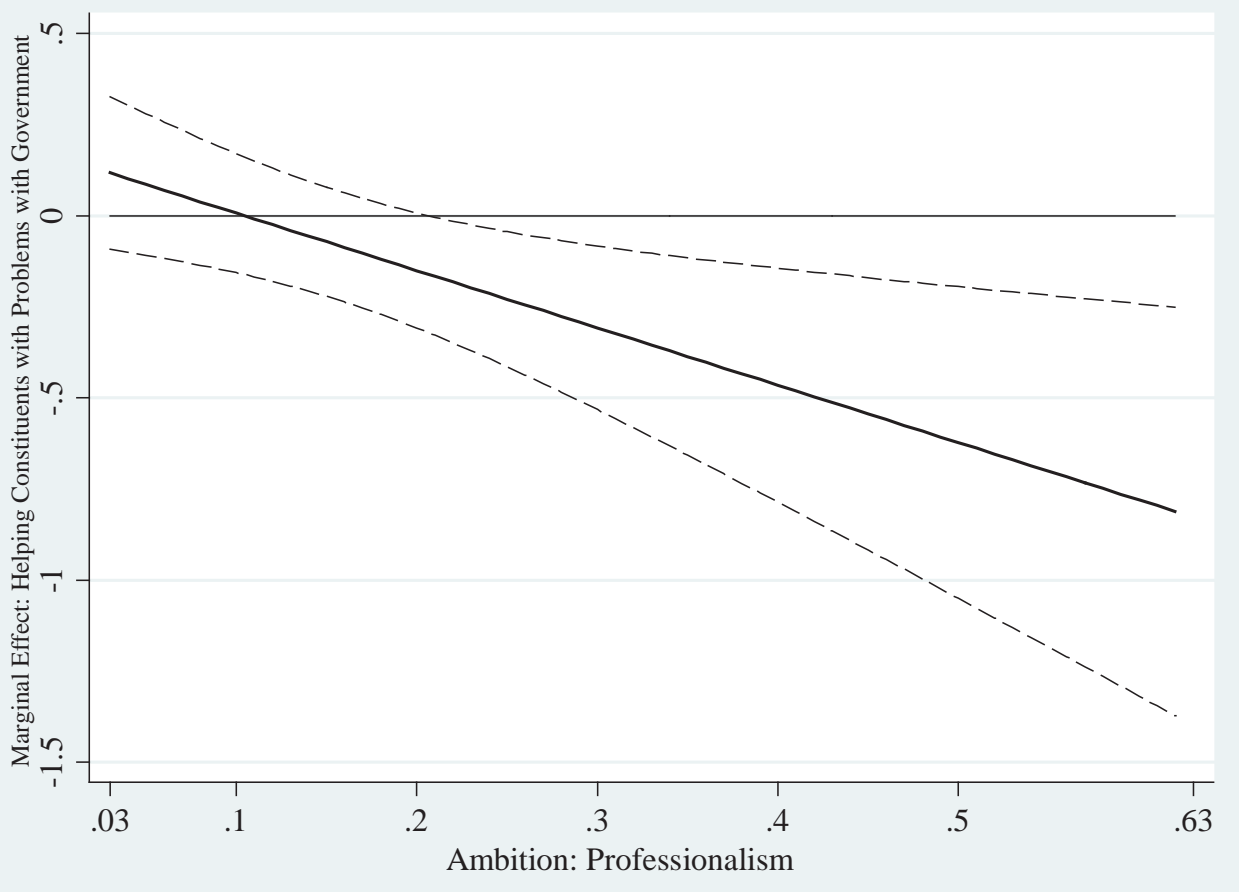


This is an author-produced, peer-reviewed version of this article. The final, definitive version of this document can be found online at Politics \& Policy, published by Wiley-Blackwell. Copyright restrictions may apply. doi: 10.1111/polp.12072

Table 3: Results for Total Effect of Term Limits in OLS Models 2, 4, and 6

\begin{tabular}{|l|c|c|}
\hline \multicolumn{1}{|c|}{ Model } & $\begin{array}{c}\text { Short Term Goals } \\
\text { (Outside Pay) }\end{array}$ & $\begin{array}{c}\text { Career Politician } \\
\text { (No Outside Pay) }\end{array}$ \\
\hline Keeping in Touch with Constituents & $-0.182 *$ & -0.200 \\
$(0.099)$ & $(0.125)$ \\
\hline Helping Constituents & -0.118 & $\mathbf{- 0 . 2 8 0 *}$ \\
\hline Fair Share of Government Money and & $(0.099)$ & $\mathbf{( 0 . 1 5 5 )}$ \\
Projects & -0.065 & $\mathbf{- 0 . 3 2 3 *}$ \\
\hline \multicolumn{2}{|c|}{$(0.124)$} & $\mathbf{0 . 1 6 6 )}$ \\
\hline
\end{tabular}


Table 4: Campaigning and Fundraising Models

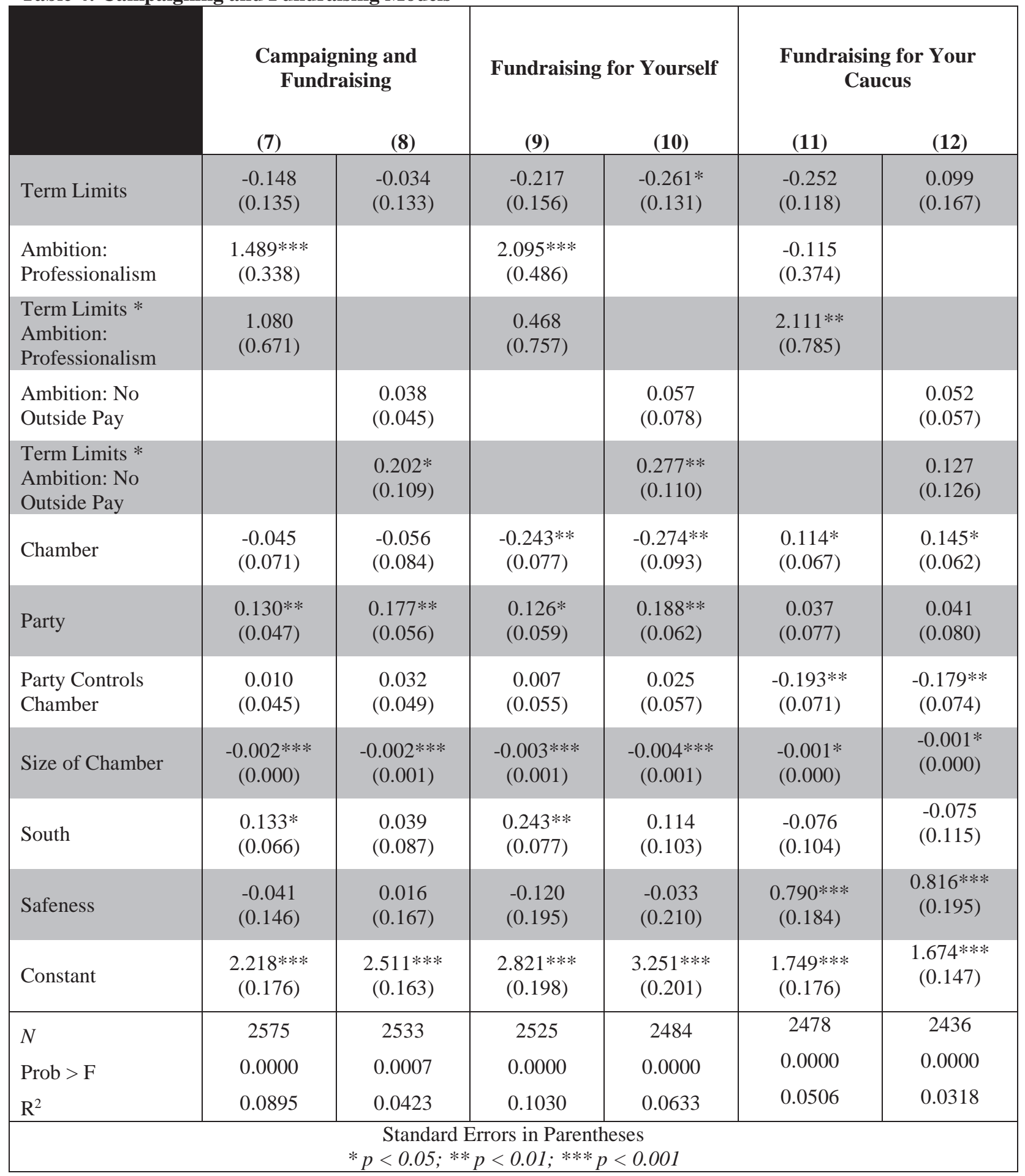


Graph 3: The Marginal Effect of Term Limits on Fundraising for Your Caucus

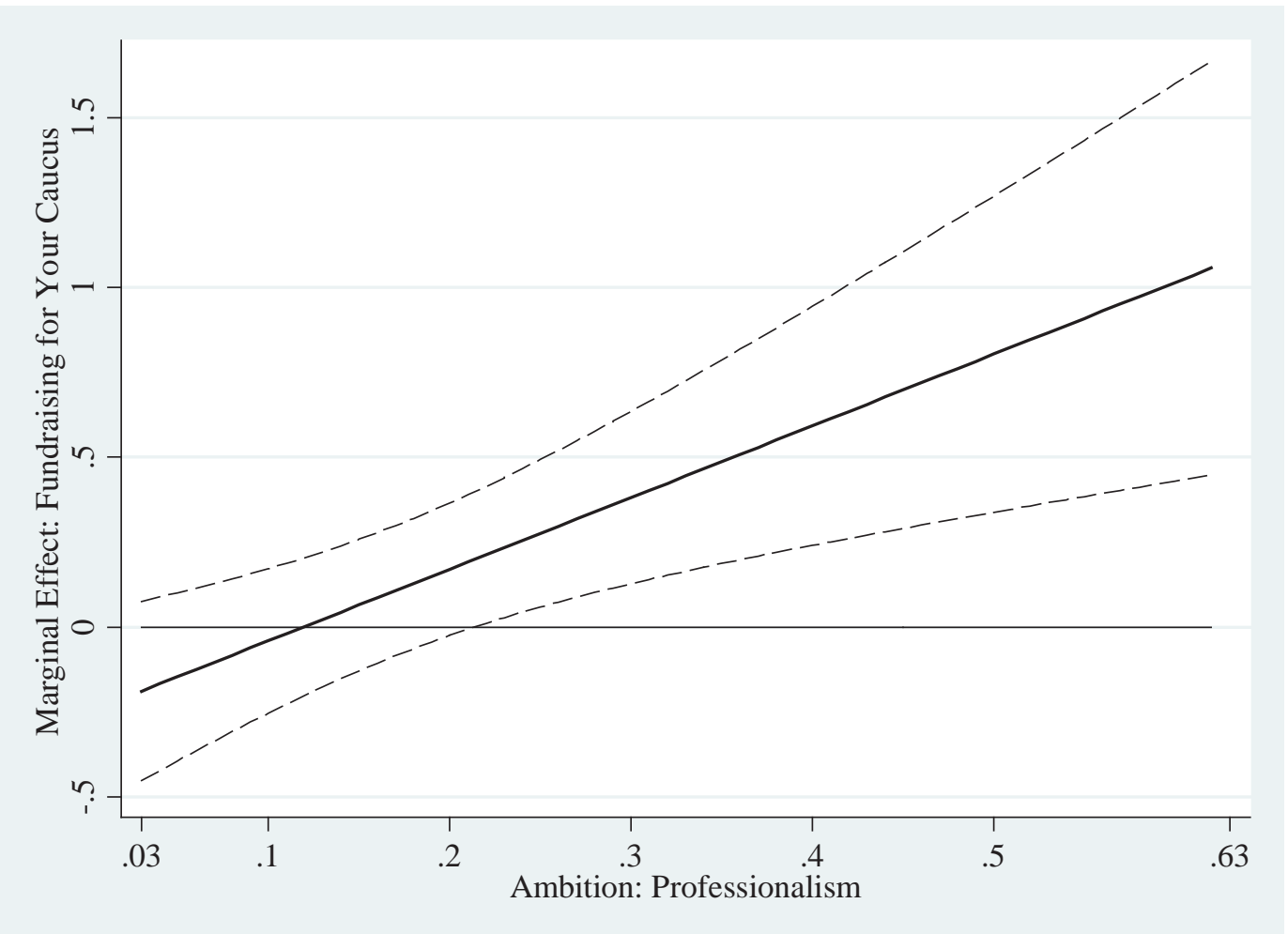

Table 5: Results for Total Effect of Term Limits in OLS Models 8, 10, and 12

\begin{tabular}{|l|c|c|}
\hline \multicolumn{1}{|c|}{ Model } & $\begin{array}{c}\text { Short Term Goals } \\
\text { (Outside Pay) }\end{array}$ & $\begin{array}{c}\text { Career Politician } \\
\text { (No Outside Pay) }\end{array}$ \\
\hline Campaigning and Fundraising & $\begin{array}{c}-0.034 \\
(0.133)\end{array}$ & $\begin{array}{c}0.167 \\
(0.122)\end{array}$ \\
\hline Fundraising for Yourself & $\begin{array}{l}-0.261 * \\
(0.131)\end{array}$ & 0.016 \\
\hline Fundraising for Your Caucus & $\begin{array}{c}0.099 \\
(0.167)\end{array}$ & $\mathbf{0 . 2 2 6 *}$ \\
\hline \multicolumn{2}{|c|}{} & $* .138)$ \\
\hline
\end{tabular}




\section{Footnotes}

${ }^{1}$ An earlier version of this paper was presented at the 2007 Western Political Science Association meeting and the 2011 Midwest Political Science Association meeting. I wish to thank William Heller, Gregory Robinson, Michael McDonald, Michael Allen, the participants in the Comparative/American workshop at Binghamton University, and the anonymous referees and editors in chief at Politics and Policy for their useful feedback on earlier versions of the paper.

2 The district magnitude of these elections varies both between states and within states. While all states legislatures include at least some single member district seats, several also include multimember district seats. In addition, the term length for these seats varies from two to four years (Carey, Niemi, and Powell 2000; National Council of State Legislatures 2012).

3 Three states were not used in the analysis: Idaho, Oregon, and Nevada. Since Idaho and Oregon repealed term limits in early 2002 (shortly before the survey was conducted), I did not include them in the sample. The early effects of these repeals may have had unusual effects on legislators' behavior. Before the repeal, these legislators were working under the assumption that they would only serve short-term legislative careers. Immediately after term limits were repealed, they had a new career option, being a lifetime legislator, and they may have been readjusting their long-term political career goals (and their behavior) in response to this new option. Furthermore, I did not include Nevada because term limits in Nevada do not apply to all Nevada legislators. Although the state introduced term limits in 1996, the Nevada Legislative Council and the Attorney General ruled that term limits could not be applied to legislators elected in the same year term limits were passed (National Council of State Legislatures 2002, 2010, 2011a).

${ }^{4}$ It is important to note that although Ambition: Professionalism and Ambition: No Outside Pay are meant to capture whether a legislator is a career politician, these variables are only correlated at the 0.2351 level. This result is not surprising, however, since Ambition: No Outside Pay is a dummy variable and as such, it is more difficult to find a statistical correlation between the two variables. Correlation measures the extent to which individual observations vary from the means of two variables in a similar magnitude, and in which direction. Since Ambition: No Outside Pay is a dummy variable, each observation varies from its mean by the exact same magnitude in either a positive or negative direction while there is a great deal more diversity in the magnitude of the individual variations from the mean in the Ambition: Professionalism variable. As a result, the correlation coefficient is depressed towards 0 . The positive correlation does suggest, however, that legislators in more professionalized legislatures are less likely to work for outside pay, which is what I expect.

${ }^{5}$ Including interaction terms in regression models may introduce concerns about multicollinearity in the models. However, the effects of mulitcollinearity in models with interaction terms are generally minimal. It may initially appear that adding an interaction term causes issues with the values of the coefficients and may increase the standard errors of the key variables of interest, but this is not the case. The calculation and interpretation of coefficients and standard errors in a model with an interaction term are purposefully different from a model with no interaction term. If there is an interactive effect between two independent variables on a dependent variable, a regression model with an interaction term can determine this effect as long as the proper steps are taken to correctly calculate and interpret the coefficients and standard errors of the independent variables (Brambor, Clark, and Golder 2006; Friedrich 1982).

${ }^{6}$ Carey et al. (2006) included several other control variables in their models. The data for these variables are not included with the accessible dataset.

${ }^{7}$ For a more technical discussion regarding the calculation of marginal effects in interaction models, see Brambor, Clark, and Golder (2006).

${ }^{8}$ Evidence from cases outside the United States also demonstrates that politically ambitious legislators who face term limits rely heavily on party leaders to continue their political careers outside legislative office. For example, in Costa Rica, term limited deputies are able to maintain their political careers outside the Legislative Assembly if the incoming President is a member of their party and is able to appoint them to highly valuable government posts (Carey 1996). 